\title{
Patterns in tropical leaf litter and implications for angiosperm paleobotany
}

\author{
Robyn J. Burnham \\ Museum of Paleontology, University of Michigan. Ann Arbor, MI 48109-1079, USA
}

(Received March 8, 1993: revised and accepted July 13. 1993)

\begin{abstract}
One hectare of undisturbed Amazonian forest, containing about 175 species of trees larger than $10 \mathrm{~cm}$ diameter at breast height. was studied to determine the relationship between high-richness forest and the autochthonous litter produced by the forest. Litter samples contained up to 52 species, of which one-third represented epiphytes, vines, and lianas.

These modern leaf litter studies from southeast Amazonian Peru indicate that reconstructions of ancient highdiversity forests are possible using autochthonous leaf litter deposits. In comparison to temperate litter samples, however, more sampling must be done to recreate fairly simple descriptors of ancient communities such as species richness and heterogeneity. Samples must be large, relatively closely spaced, and maintained as distinct collecting localities to retrieve the maximum amount of data from rich, angiosperm-dominated localities. There are many advantages justifying more intensive collections. For example, biomass contribution of major life-form categories in the source forest is reflected in leaf litter accumulating under tropical forest canopies. Tropical forests, because of their extreme heterogeneity, also can provide the opportunity to reconstruct individual species characteristics from litter signatures. The relative rarity of most species creates distinct leaf shadows from which the canopy breadth and volume of many individuals can be estimated. The principles derived from modern tropical litter studies can be applied to existing fossil collections; however, their power lies with those collections originating from autochthonous assemblages. for which spatial control during collecting has been maintained, and time averaging has been kept to a minimum. These reflections of community structure available from the leaf litter provide a means for paleobiologists to contribute significantly to the study of community evolution and stability.
\end{abstract}

\section{Introduction}

There are certain types of fossil plant deposits for which indications of fine-scale ecological data can be retrieved. These are exceptional deposits, but not uncommon in the fossil record. Angiosperm-dominated deposits of this type have been recognized throughout western North America and range in age from Late Cretaceous through to the Recent (Cross and Taggert, 1982; Wing. 1984; Boyd, 1985; Johnson, 1992; Wing et al., 1993; Burnham, in press). The characteristics of such leaf deposits are:

(1) they are accumulations of plant litter that have not been transported far from their point of abscission from the source plants (autochthonous or parautochthonous);

(2) they show fine detail in shape and venation, such that identification of a large proportion of the leaves is possible;

(3) they are exposed over large areas, such that lateral variation in the composition of the bed can be determined: and 
(4) they show indications that sedimentation was rapid, with complete burial of the plant litter in a single event or a few, closely spaced, event-deposits.

The coincidence of all these features in a fossil plant deposit indicates that the potential for extraction of high-quality ecological data is possible. These same deposits offer some of the best possibilities for complete systematic studies. Although the ecological importance of plant "lagerstätten" is appreciated by the majority of paleobotanists, systematic concerns commonly take the front seat in collection efforts whereas the taphonomic and ecologic context of the plants may be given only a cursory analysis, if any, in the ensuing monographic treatment. There has not been, until recently, much attention paid to the methods by which fossil plants should be collected and analyzed if the highest-quality ecological data are to be extracted.

Sampling methods for fossil assemblages have been investigated directly using a variety of censusing methods (reviewed by Scott, 1977; Spicer, 1988 ), but the meaning of quantitative counts (e.g. Spicer and Hill, 1979) has been open to various interpretations. Innovations in fossil plant sampling for ecological analysis must follow the guidelines derived from studies in modern sedimentary environments on the formation of the assemblages. Currently several researchers are approaching the processes of plant fossilization in modern environments from a variety of angles (Burnham, 1989; Gastaldo, 1989, 1992; Burnham et al., 1992; Greenwood, 1992). The present research is focused on one of the first steps in the fossilization process, that of primary litter accumulation, for two reasons. First, because most plant parts enter the fossil record through this first step, a thorough understanding of the process is essential to any plant taphonomic interpretation. Second, in-place litter accumulations are not uncommon in the fossil record and these provide some of the best possible evidence on original community structure. Therefore, a complete understanding of the way in which the source forest is reflected in the primary, untransported litter is essential. It is through these attempts at understanding the individual steps in the fossilization process that the means for efficiently sampling fossil outcrops will emerge.
It is the purpose of this paper to present investigations on modern leaf litter accumulations in a moist tropical forest for the purpose of extracting guidelines for the collection and analysis of highdiversity fossil plant deposits. These guidelines should accommodate both the systematic and the ecological interests of paleobotanists. Analogous interpretations of ancient litter accumulations can be drawn safely only to those deposits that have the characteristics outlined above.

\section{Site description and methods}

\subsection{Site description}

Research was carried out at the Pakitsa Guard Station of the Parque Nacional del Manu in the Department of Madre de Dios, Perú (Fig. 1). The Pakitsa site $\left(11^{\circ} 54^{\prime} \mathrm{S}, 71^{\prime} 22^{\prime} \mathrm{W}\right)$ is located at approximately $340 \mathrm{~m}$ elevation on the Rio Manu, a white water river that drains the Peruvian highlands from an elevation of $2000 \mathrm{~m}$ and joins the Madre de Dios at $320 \mathrm{~m}$ elevation. At Pakitsa, the Rio Manu is a meandering river with a high suspended load. Cut-off meander lakes are common, locally known as cochas. Mean annual temperature at Cocha Cashu Biological Station,

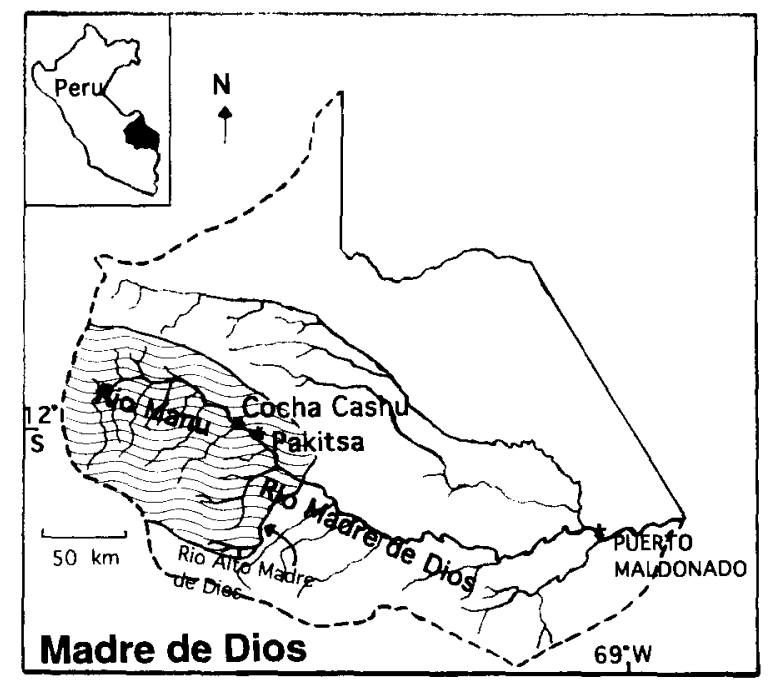

Fig. 1. Location of department of Madre de Dios, Perú (inset) and location of study area at Pakitsa near the Río Madre de Dios. The Parque Nacional del Manu is indicated by wavy lines. 
located $16 \mathrm{~km}$ to the northwest, is $24.1^{\circ} \mathrm{C}$, with temperature excursions reaching lows of $15^{\circ} \mathrm{C}$ and highs of $32^{\circ} \mathrm{C}$ possible in almost every month of the year (Kalliola et al., 1987). Annual precipitation at Cocha Cashu is $2080 \mathrm{~mm}$, which is distributed primarily during the months of November through May. Humidity is generally high. During the dry months it is not unusual to receive less than $10 \mathrm{~cm}$ of rain, although yearly rainfall patterns are extremely variable (Terborgh, 1990).

In general, the forests at Pakitsa and along the Rio Manu are heterogeneous in aspect, due to varying water tables, soil types and forest ages (Terborgh, 1983). This study is centered on a single hectare of forest (known as Zone 2) which supports about 175 tree species larger than $10 \mathrm{~cm}$ diameter at breast height ( $\mathrm{dbh}$ ), but it is notable that a second hectare, only $2 \mathrm{~km}$ away shares only $34(20 \%)$ tree species. The hectare of forest reported here occupies a relatively low, cut-bank position along the Río Manu and can be classified as a moist tropical forest originating on a rich alluvial soil. Canopy dominants belong to the Bombacaceae, Leguminosae, Moraceae, Tiliaceae, Sapotaceae, and Rubiaceae. The forest is composed of only a few tree species that remain leafless for longer than 2 months. Many of the trees lose their leaves for a short period of time (2-4 weeks) during the dry season, and others (classically termed "evergreens") simultaneously produce new leaves and shed old ones during the dry season. The forest contains at least 6 species of palms with a dbh larger than $10 \mathrm{~cm}$. Three species of palms are very abundant, making the family the most abundant in terms of stem number on the mapped hectare.

\subsection{Forest mapping}

The forest hectare reported upon here was mapped by the BIOLAT (Smithsonian Institution) team working at Pakitsa during SeptemberOctober 1988. All trees larger than $10 \mathrm{~cm}$ dbh were measured, identified and mapped. Lianas were included only if they met the diameter limit. Data were compiled into map form with identities of each tree, diameter at breast height and exact position of each tree plotted. Tree identifications were made by Dr. Robin B. Foster. Maps were verified by the author during each of three subsequent field seasons, with minor modifications made to the original maps. Thus, for the forest to which the litter is compared, a high-quality description is available for all canopy and subcanopy tree species. This well-characterized forest hectare is referred to hereafter as the source forest. To aid litter identifications, samples of leaves from each species were collected from identified trees on the hectare as well as naturally dried leaves from forest litter of each species.

\subsection{Litter collection and quantification}

Litter was collected from the forest floor in 13 $0.5 \times 0.5 \mathrm{~m}$ sample quadrats during October 1990 . Litter sampling was carried out only in the central $40 \times 40 \mathrm{~m}$ of the hectare, leaving a mapped buffer zone of $30 \mathrm{~m}$ around the outside of the sampling area (Fig. 2). This ensured that very few individuals could be represented in the litter samples that were not accounted for in the source forest. All identifiable litter fragments were collected from the forest floor, including identifiable leaf rachises, fruits and seeds. Only the leaf fraction of the litter is used here for comparison with the standing forest. Litter was dried first in the field in mesh net bags and then returned to the USA for identification, complete drying and weighing. Foliage material was separated to species, counted, dried to a constant weight at $70^{\circ} \mathrm{C}$, and each species weighed indepen-

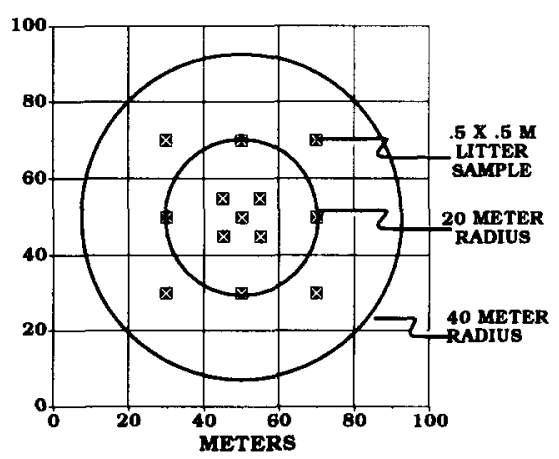

Fig. 2. Litter sample collection sites in Zone 2 hectare, Pakitsa Guard Station, Manu National Park, Perú $(\times$ marks $0.5 \times 0.5$ $\mathrm{m}$ litter collection sites). Circles show two examples of forest areas compared to litter samples. 
dently. Unidentifiable leaves were given a morphotype letter and an example of each morphotype was saved for later identification. The "unknown" taxa are not included in any of the considerations presented here, unless explicitly stated.

\subsection{Comparative methods}

The leaf litter and source forest were compared using both qualitative (presence-absence lists) and quantitative (biomass) comparisons. Presenceabsence comparisons use species lists from litter and source forest and only identified litter taxa are considered here (Appendix 1). Comparisons of species numbers in three habit classes use all taxa for which habit class can be reasonably inferred, regardless of the ability to identify the leaf. Litter distribution of individual species are compared using leaf numbers, which is appropriate for singlespecies comparisons.

Rank-order comparisons were made on the basis of proportion stem basal area and proportion litter mass. These two attributes were chosen because (1) basal area more closely approximates species importance than does stem number in highdiversity forests, and (2) litter mass circumvents the problem of numerical over-representation of compound leaves by leaflets, created by leaf number comparisons. The best proxy for leaf mass in fossil assemblages is leaf area (Burnham et al., 1992) which is most accurately calculated by counting number of leaves or leaflets and multiplying by leaf area of a complete specimen (leaf or leaflet).

\section{Results}

\section{I Species presence-absence comparisons}

The average number of leaves or leaflets counted per sample was 426 (range 236-671). Average number of taxa identifiable to species was 25 per sample (range 20-33). An average of 10 additional, distinct taxa that were not assignable to known species was also found in each sample. Familiarity with the forest and evidence from leaf morphology indicate that most of these "unknowns" are canopy vines.
Using the most simple comparison, that of single samples to the source forest, an average of $11.4 \%$ of the source forest tree species are found in a single sample (range 8-15\%). This can be compared to the results reported by Burnham (1993) on temperate forests in which single litter samples contained an average of about $70 \%$ of the species from source forests. Because these values are derived from the comparison of only $0.25 \mathrm{~m}^{2}$ of litter to a hectare of diverse source forest, a more appropriate comparison, particularly in tropical forests, is made between a single sample and the source species within a limited radius of source forest. The radius that maximizes the proportion of litter species accounted for in the source forest and vice versa is a radius of $12.5 \mathrm{~m}$. The average proportion of species in a $12.5 \mathrm{~m}$ radius source forest represented in single litter samples is $(40.3 \%)$. This can be compared to the results reported by Burnham (1993) on temperate forests in which single litter samples contained $80-90 \%$ of the species in a $15 \mathrm{~m}$ forest radius.

An even more reasonable comparison of presence-absence lists is between several litter samples and a specified area of source forest. Two such comparisons are presented in Fig. 3, in which combined species lists from the five central samples were compared to forest areas with (a) 15 and (b) $20 \mathrm{~m}$ radii. Approximately $70 \%$ of the species present in the source forest are represented in the litter species lists from five combined samples. Further, if all thirteen samples derived from the central $40 \times 40 \mathrm{~m}$ area are combined and compared to the entire surrounding forest hectare, the proportion of source species represented in the litter samples is $43 \%$ (Fig. $3 c$ ).

In all these various areas of source forest, it is significant to note that $80-90 \%$ of the woody biomass (as defined by cross-sectional area of tree trunks) is accounted for by the species represented in the corresponding list for litter samples (Fig. 3). Thus, the ecological dominants are well represented.

\subsection{Missing taxa}

Missing taxa are informative because these are the taxa that would be "unseen" or misinterpreted 


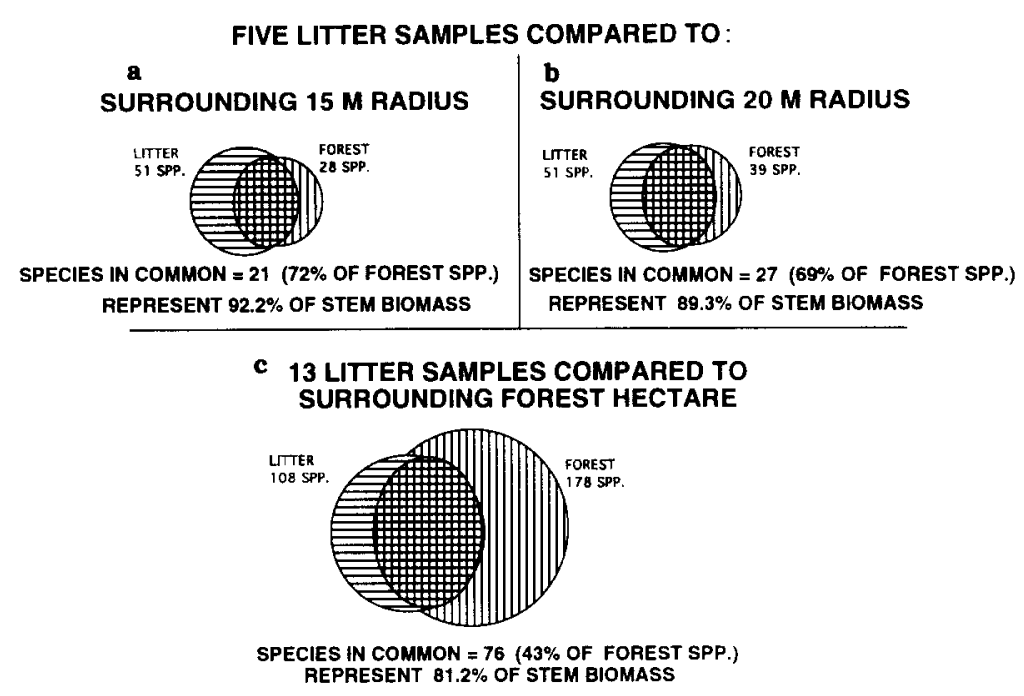

Fig. 3. Presence absence comparisons between litter and source forest species lists. Horizontal bars represent species found in litter but not in forest area. Vertical bars represent species found in forest area but not in litter samples. (a) Combined litter species list from 5 samples in central $10 \times 10 \mathrm{~m}$ area compared to a $15 \mathrm{~m}$ radius source forest. (b) Combined litter species list from 5 samples in central $10 \times 10 \mathrm{~m}$ area compared to a $20 \mathrm{~m}$ radius source forest. (c) Combined litter species list from 13 samples in central $40 \times 40$ $\mathrm{m}$ area compared to a one hectare source forest.

if found as a single isolated leaf in a fossil reconstruction. The patterns of missing taxa are similar in all cases studied. They will be illustrated here by using the comparison of 5 combined litter samples to a $20 \mathrm{~m}$ radius source forest (Fig. 3b). The taxa that are present in the litter samples but not represented in the $20 \mathrm{~m}$ radii of source forest (Fig. 3b, horizontal lines) belong primarily to two categories. First, 41\% of the "missing" source species are very large trees outside the $20 \mathrm{~m}$ radius forest. Second, $25 \%$ of the "missing" source species are identifiable canopy vines and lianas (particularly members of the Bignoniaceae and Menispermaceae). Small trees, herbs and epiphytes make up about $9 \%$ each of the litter species "missing" from the source forest list. The proportion of canopy vines/lianas is clearly underrepresented by these statistics which do not include unidentified taxa, many of which are also vines/lianas.

On the other hand, there are trees in the designated $20 \mathrm{~m}$ radius not encountered in the litter (Fig. 3b, vertical lines). The twelve source tree species not represented in the litter are all small individuals of rare species. Only 3 species are represented by more than one tree in this $20 \mathrm{~m}$ radius forest. Only one species has a dbh over $20 \mathrm{~cm}$. Of the group of twelve species, half have very large leaves (macrophylls, e.g. Gustavia hexapetala, Coccoloba lehmanii, Sloanea fragrans). Although it is possible to find leaves of these species underneath the canopies of the trees, they are few in number. The production of few large leaves predisposes a tree to underrepresentation in the litter and may severely bias climatic reconstruction based on foliar physiognomy. The other half of this group have leaves of mesophyll size and their underrepresentation can only be attributed to a small canopy volume.

\subsection{Life-form representation}

Setting a lower limit to tree diameter mapped in the forest has the potential to cause errors in the comparisons of litter and forest because the smaller-diameter species below the mapped size limits (i.e. $<10 \mathrm{~cm} \mathrm{dbh}$ ) may be represented in the litter but not in the source forest. Although this is a possibility, it appears to have little influence on these data. Instead, the majority of the species that are found in litter samples but not accounted for by the source forest are one of two classes: either 
large trees beyond the forest area sampled or vines/lianas. The low biomass produced by small dbh trees has a proportionately minor influence on the litter.

Fig. 4 shows the proportion of species in the litter accounted for by each of three categories: trees, vines/lianas, and herbs/epiphytes. These tabulations include all "unknowns" to which life form could be assigned with a reasonable degree of certainty. Between 13 and $32 \%$ of the species of each sample are vines/lianas. It is important to note that although there is a high diversity of epiphytes, herbs, and small trees in the forest at Pakitsa, their total biomass is low (as gauged by cross-sectional area and by photosynthetic area) and these life-forms are virtually unrepresented in the litter. This indicates that the litter is more a reflection of the species and life forms that play the largest role in total photosynthetic area, than it is a list of all species present in the area. Total numbers of these life forms has not been determined in the source forest, but Foster (1990) reported the following proportions for life forms in combined Manu floodplain forest floras: trees, $28 \%$; shrubs, $28 \%$; lianas, $18 \%$; herbs, $14 \%$; epiphytes, $12 \%$.

A significant deviation from the generalization made above is in the proportion of palms that are represented in the litter. Palms are represented by 6 tree-sized species in the source hectare. They are the dominant family by number of stems and

\section{HABIT SUMMARY OF SPECIES IN LEAF LITTER}

MANU National PARK, PAKITSA, PERU

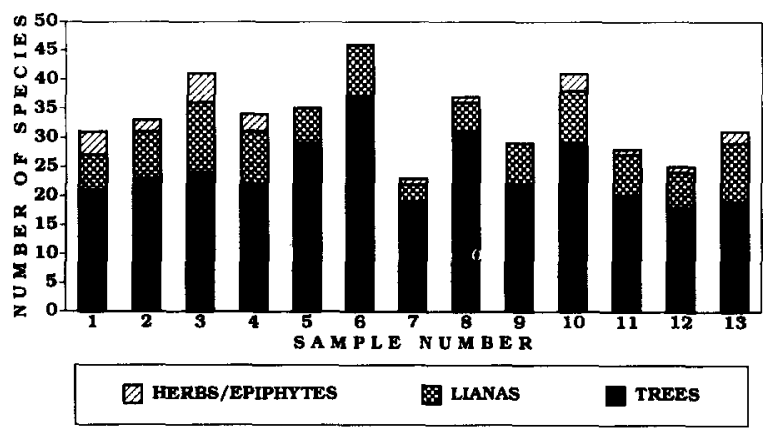

Fig. 4. Proportion of litter species represented in three lifeform categories. Litter species include all taxa recovered from litter samples for which life form is known with reasonable certainty. contribute $11 \%$ of the stem basal area of the hectare. There is no doubt that they are quite important to the ecology of the hectare. Interestingly, however, palms are represented in almost every litter sample by only a very small amount of degraded foliage material (usually one or rarely two species), which represents only $3^{\%}, 1$ of the combined biomass of all samples. These observations parallel the observations on palms made by Gastaldo and Huc (1992) and Gastaldo (1992) from the Mahakam Delta.

\subsection{Individual species litter shadows}

Litter shadows of trees of four species are shown in Fig. 5. Leaves were counted in a $0.5 \times 0.5 \mathrm{~m}$ area at every meter along transects made in three radial directions away from the trunk of each tree. The species illustrated were chosen because of their relative (or absolute) rarity on the hectare and the range of stem diameters encompassed by the group of species. Canopy edge and estimated canopy height of each tree is noted.

There is a significant drop in abundance of leaves at the canopy edge in all cases. This indicates two things: (1) leaves are falling, for the most part, out of the canopy directly to the forest floor and experiencing little post-abscission redistribution on the forest floor, and (2) for isolated individuals of a species, the canopy edge may be discernible from autochthonous litter deposits. Note that in all cases, some leaves are distributed beyond the canopy edge.

Although the measurement of individual canopy height in the source forest was purely by estimation and is likely to be inaccurate particularly for the taller trees, there is a strong suggestion that the canopy height and the furthest absolute distance leaves are distributed from the trunk of the tree are related linearly. Leaves tend to be distributed to a maximum distance roughly equal to the canopy height. The usefulness of this relationship is limited to those fossil assemblages in which no traumatic or post-abscission transport has occurred. Confirmation of the results of the shadow distributions on additional species from Cocha Cashu Biological Station is underway but 

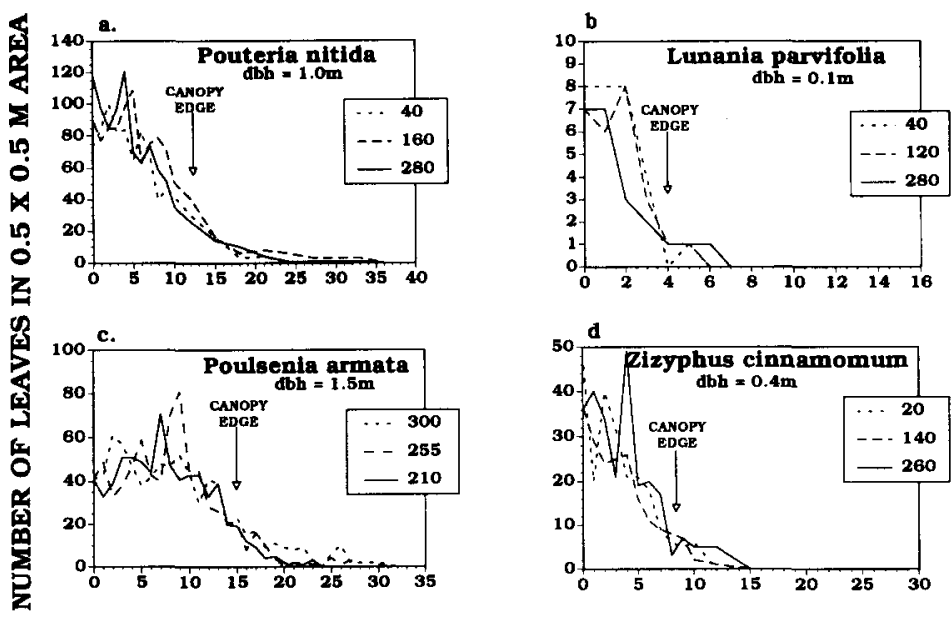

DISTANCE FROM TRUNK OF TREE (M)

Fig. 5. Litter shadows for individual trees of four species. Shadows were made by counting all leaves of the target species in at $0.5 \times 0.5 \mathrm{~m}$ area at $1 \mathrm{~m}$ intervals along three transects which originated at the tree bole. Tree bole position is at 0 in all cases. Tree canopy extent is indicated. Approximate tree heights are Pouteria nitida, $40 \mathrm{~m}$; Lunania parrifolia, $6.5 \mathrm{~m}$; Pouslenia armata, $40 \mathrm{~m}$; Zizyphus cimnamomum, $12 \mathrm{~m}$. Boxed numbers indicate the three compass directions per tree along which leaves were counted on the three transects.

preliminary results strongly support the patterns presented in Fig. 5.

The preceding litter shadows were generated by a very intensive sampling regime (1 $\mathrm{m}$ intervals) focused on a single individual tree in each case. If reconstructions are to be made of many trees of many species from fossil samples, it is more likely that generalized sampling will be carried out in a manner similar to the distribution of the 130.25 $\mathrm{m}^{2}$ samples made from litter accumulations for this study. Thus, four tree species were targeted from those 13 litter samples and the distribution of leaves of these species is shown in Fig. 6. Isographic contours are shown, created by interpolating betweeen the thirteen sampling sites within the central $40 \times 40 \mathrm{~m}$ area. Canopy breadth and trunk diameter of the trees are indicated. Only leaves of large canopy trees (30-40 m in height) were selected for this figure because the number of leaves from any small tree is very low except right under the tree canopy.

Attributes of canopy size and shape can be inferred from litter patterns from the samples, but these inferences are made stronger by knowledge of the results from the finer-scale sampling on the transects shown in Fig. 5. For example, the shadow of the same individual of Poulsenia armata is shown in both figures (Figs. 5c and 6c). In Fig. 6c, the dramatic drop in leaf abundance at the canopy edge is not plotted because abundances are interpolated between the thirteen litter collection points of the hectare (i.e. sampling is not dense enough to pick up the drop). Note particularly that Fig. $6 \mathrm{c}$ interpolates 25-30 leaves at a distance of $20 \mathrm{~m}$ from the trunk. In fact, as Fig. $5 \mathrm{c}$ shows, there are at most 12 leaves at a distance of $20 \mathrm{~m}$ from the trunk. This indicates that the density of sampling of fossils must be on the appropriate scale to pick up litter abundance drops.

If fossil sampling can be extended at least to a $40 \mathrm{~m}$ transect, finer resolution of the canopy attributes can be made. To correlate the litter pattern with the exact position of the trunk of the tree, it is necessary to bisect the canopy shadow completely (note particularly Fig. 6d for Spondias mombin). To estimate canopy breadth, the largest drop in abundance of leaves can be read directly from the litter pattern and would correlate with the edge of the canopy. To estimate approximate canopy height, the maximum distribution of leaves must be known. Overlapping canopies of conspecifics will eliminate the possi- 

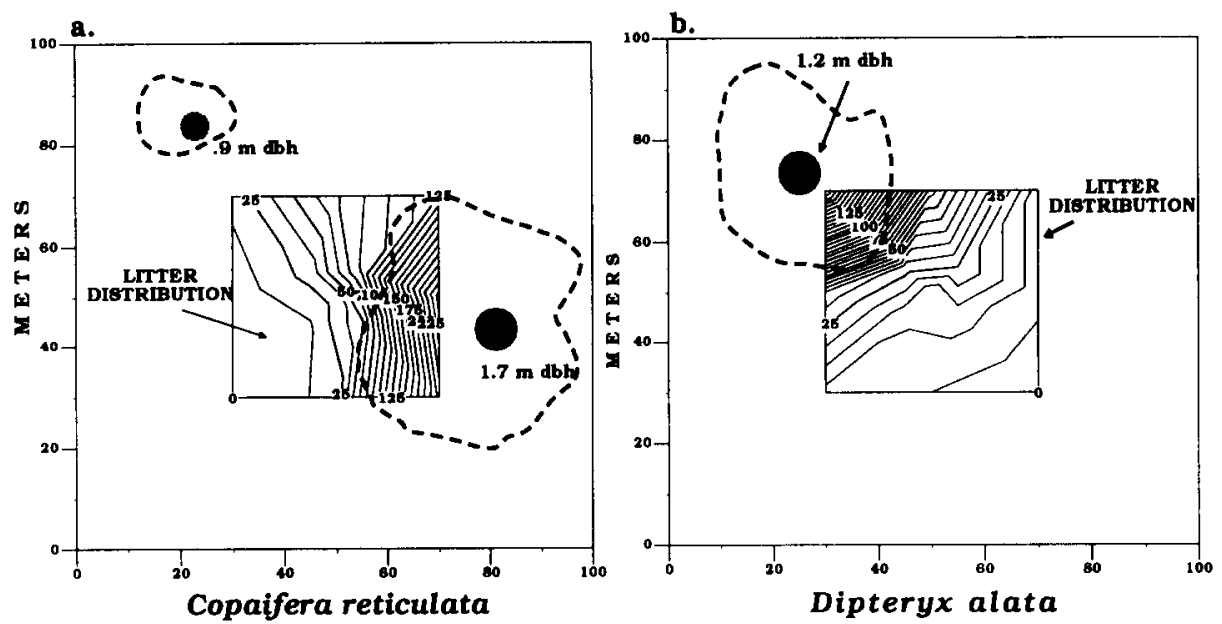

c.

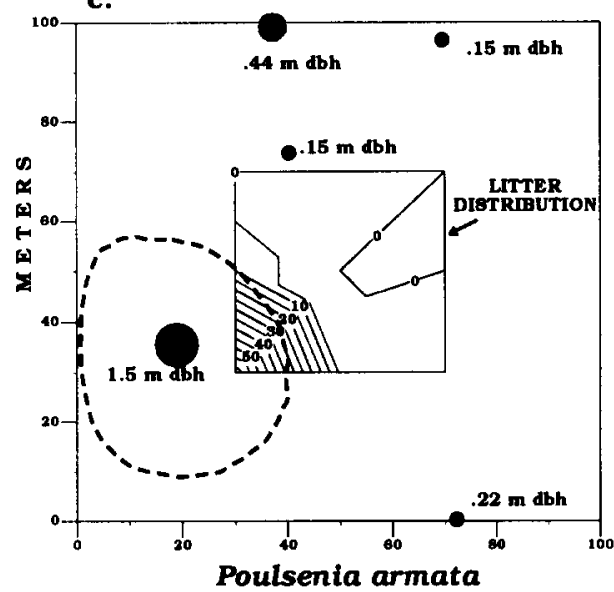

d.
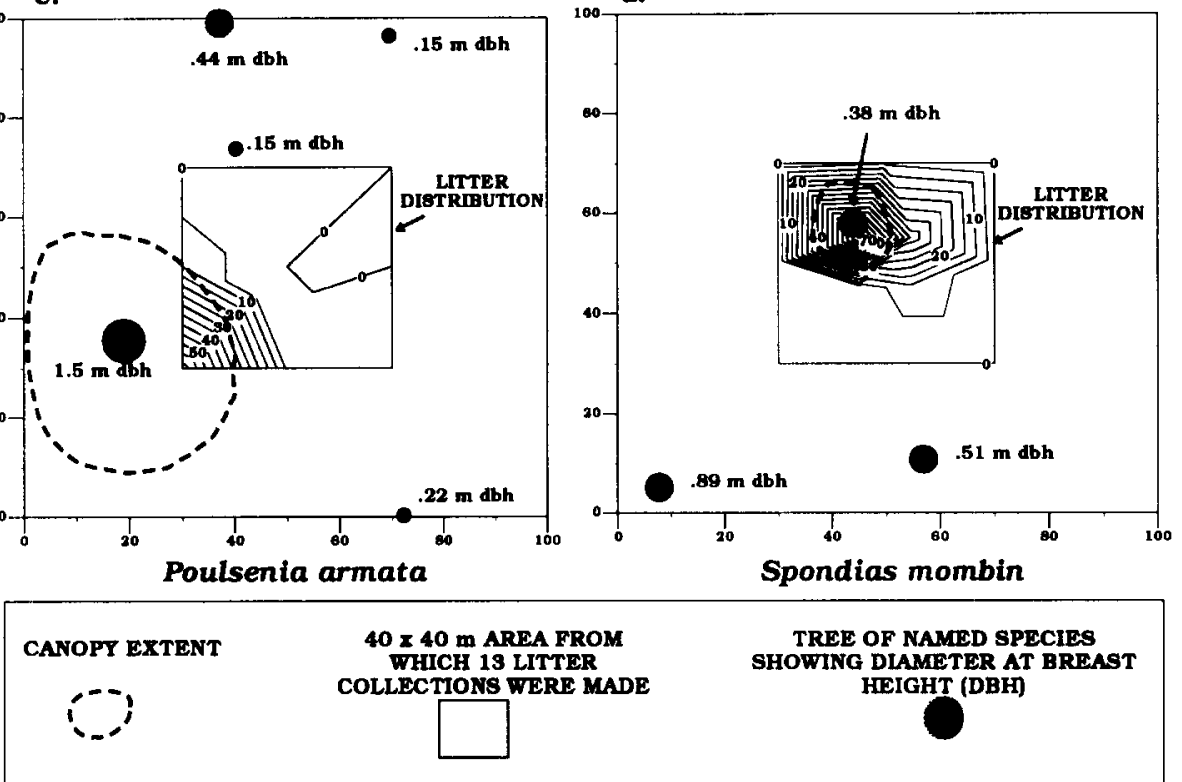

Fig. 6. Litter abundance in 13 litter samples for 4 targeted species. Number of leaves per sample is shown as isographic contour Tree bole position(s) are shown as well as canopy extent.

bility of extracting such autecological data from the fossil record.

Autecological data can be retrieved from diverse fossil assemblages if the sampling regime is sufficiently dense and carried out over a sufficiently large area. A rule of thumb indicated for individual attributes would be that sampling density should be on the order of one sample at least every $7 \mathrm{~m}$, and that the sampling should be carried out over an area of twice that of the estimated canopy height.

\subsection{Rank-order representation of forest dominants in litter}

Rank-order comparisons of source forest and litter were made over a wide variety of combined samples and forest areas. A trade-off exists in 
selection of a source forest area between (1) including all tree taxa represented in litter, and (2) extending the source area far enough to accommodate the first parameter such that trees, unrepresented in litter, also are included. The rank-order comparison that maximizes the similarity between dried litter mass representation and forest stem diameter representation is a comparison between source forest with radius of $40 \mathrm{~m}$ and all 13 litter samples (determined by Spearman rank-order correlation values). This includes a mapped forest area beyond the litter sample area of a minimum of $12 \mathrm{~m}$ (see Fig. 2).

The 25 most important taxa from all 13 litter samples and the 25 most important taxa from the source forest in a $40 \mathrm{~m}$ radius have been ranked in order of abundance in Fig. 7. The rank-order importance of forest taxa is based on their proportion of total stem biomass as measured in crosssectional diameter. Rank-order importance of litter taxa is determined on the basis of their proportion of total leaf litter mass (dried to $70^{\circ} \mathrm{C}$ ). Taxa are listed in Fig. 7 in order of litter abundance to facilitate comparison of species rank order between forest and litter.

The rank of source forest and litter species do not follow the same order and the results are disappointing when compared to similar results of a rank-order comparison in a temperate litter study (Burnham et al., 1992). However, it is important to recognize that 21 of the 25 most important source forest taxa are at least represented in the litter. Thus, there is confirmation of the results from the presence-absence data that the most important taxa are present in the litter. Of the five most important taxa in the forest, four are represented among the 10 most important taxa in the litter, and this one exception is a palm, which are poorly represented in general (see above). Similarly, of the five most important litter taxa, all are among the ten most important taxa in the source forest. Thus, although a direct reading of taxon importance cannot be made from litter mass, general statements about dominance in the source forest are recoverable from quantitative studies.

\section{Discussion}

From the results of the litter-source forest comparisons presented here it is clear that there is not a single answer to the question, "does tropical leaf litter reflect its source forest?". Instead the question must be decomposed first into autecological vs.

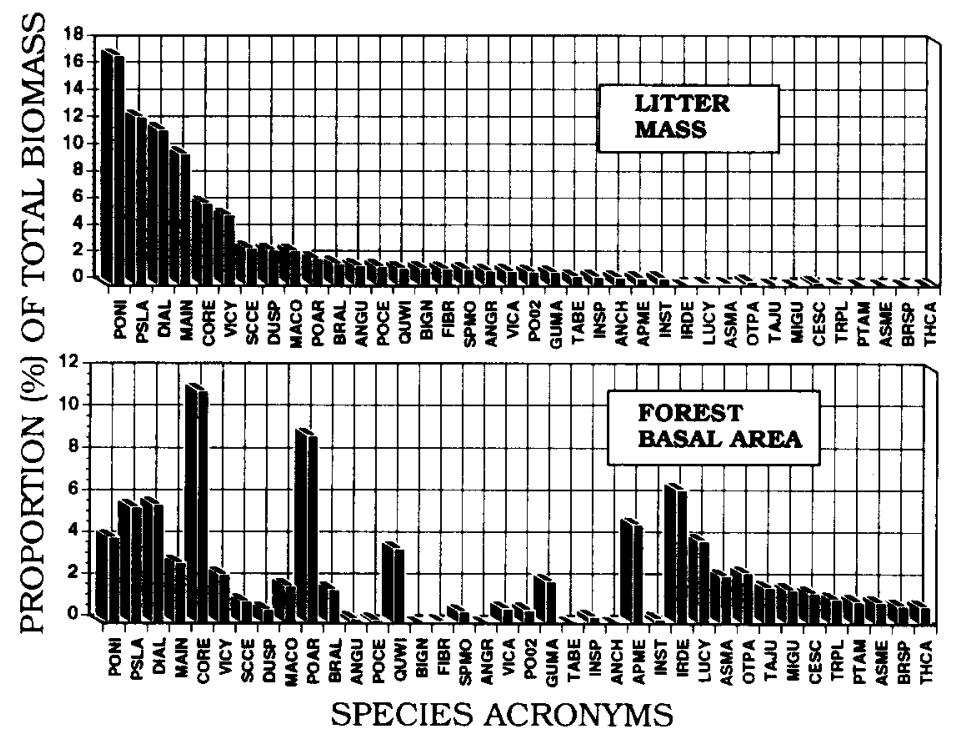

Fig. 7. Rank-order of the 25 most important litter and tree species as determined from litter mass and basal area, respectively. Both graphs are ordered here by rank order of mass of litter species. All 13 litter samples are used: source forest radius $=40 \mathrm{~m}$. 
community questions. Autecological attributes include habit, canopy characteristics and distributions, while community attributes include species richness, heterogeneity, composition of life forms, and absolute or rank-order importance. For each of these attributes, the data presented here provide an indication of the trust that we can place in the reconstructions based on autochthonous litter.

\subsection{Autecological attributes}

Plant habit may be one of the most difficult attributes to reconstruct using litter patterns only. This is because plant habit alone does not provide a unique litter distribution pattern. For example, the litter shadow of canopy lianas may have a similar form to the litter shadow of subcanopy tree species $(\sim 20 \mathrm{~cm} \mathrm{dbh})$ for which individuals are distributed patchily. In both cases a diffuse distribution of leaves would be expected over the sampling area because of the moderate number of leaves produced at any one place. Under a dense sampling regime, the tree should exhibit higher local abundances of leaves, that reflect actual crown positions and could be used to distinguish tree from liana. However, local abundances in leaves of liana species may be expected as well. Litter distribution, in combination with at least some knowledge of morphology and systematic affinities, is most likely to reconstruct plant habit from the fossil record.

Reconstruction of plant distribution is slightly more encouraging than plant habit. If individuals of species are isolated, sampling over large areas will allow reconstruction of crown positions. However, plant size will affect the interpretation since a cluster of subcanopy conspecifics may have a litter shadow very similar in form to a large isolated individual of a canopy tree. In this case we should expect absolute abundance (or mass) of the canopy individual to be higher than the subcanopy group because foliage area represented in the litter dramatically increases once a tree is $>50 \mathrm{~cm}$ dbh (pers. observation).

Canopy characteristics of individual tree species are the attributes that seem to have the greatest potential for reconstruction from quantitative litter studies of tropical ecosystems. Sampling along transects or over areal exposures can provide high- quality data on the canopy extent, as read from abundance drops. In addition, a complete transect starting at the trunk position of a fossil tree and extending beyond the distribution of leaves of that species will retrieve a rough estimate of canopy height. These attributes can be derived for evergreen or deciduous trees, providing that diversity is high and conspecific canopy overlap is minimal.

\subsection{Community attributes}

Total species richness clearly is an attribute that almost every paleobotanical floristic study tries to reconstruct. Indications from this study hectare (Burnham, 1993) and previous tropical and temperate forest research (Greenwood, 1991; Burnham et al., 1992) are that rules for reconstruction among forest types are not equivalent. Once it is determined that a heterogeneous high richness forest is under study, the reconstruction of richness will likely be a simple multiplicative factor, depending on the number of samples made. Based on this research, I recommend combining species lists from 5 samples of 350-500 leaves placed at intervals of $15 \mathrm{~m}$ and multiplying by $3-3.5$ to reconstruct hectare-based species richness. The richness of a forest area of $20 \mathrm{~m}$ radius is roughly equal to the richness of these five combined samples. It is important to note that although species richness is roughly equal in this last case, the actual species represented in the litter may not be those that are canopy trees larger than $10 \mathrm{~cm}$ dbh (i.e. some lianas may replace smaller trees in the list). These correction factors assume canopy structure comparable to that of today.

Forest heterogeneity also is reflected in forest litter. If heterogeneity is defined as the variability in the spatial distribution of species on a hectare, it should be one of the easiest attributes to reconstruct from litter because sample to sample heterogeneity is very reflective of the variability in the spatial distribution of species. Note that in a temperate forest, 2 samples shared $85-90 \%$ of their species whereas in this tropical Peruvian hectare, samples share $30-55 \%$ of their species (Burnham, 1993). Two contiguous $20 \times 20 \mathrm{~m}$ source forest plots from the Peruvian hectare share only 5-6 source species, a similarity of only $30 \%$. 
Comparison of life-form categories is a community attribute that was not fully expected to be correlated with litter and to some degree, it is not. Species that produce little biomass, regardless of their life form (mosses, ferns, small trees, epiphytes) are poorly represented in litter. However, those life forms of importance in representing total photosynthetic area of the forest are well represented. Because lianas are not censused by most forest richness studies (but see Gentry, 1983; Gentry and Dodson, 1987; Lott et al., 1987; Castellanos et al., 1989), it is not yet known whether litter abundances of climbers are in proportion to their representation by photosynthetic or stem area.

Curiously, palms are poorly represented in litter samples. Although present in most samples they are never abundant. This probably reflects the manner in which the palm leaves of the Pakitsa forest abscise and degrade. They remain attached to the trunk of the tree for a very long time following senescence and once they fall, they are heavy enough that they are often found lying in piles right at the base of the tree. Disintegration occurs very close to the tree. Most of the palm species represented on this forest hectare bear pinnately compound leaves. While this observation is particularly curious considering the abundance of palms in the fossil record (Eocene KissingerTipperary: MacGinitie, 1974; and Chuckanut Floras: pers. observation; Paleocene Raton Flora: Lee and Knowlton, 1917, pers. observation; and the Cretaceous Big Cedar Ridge Flora: Wing et al., 1993, pers. observation), it may be significant that the palms found most commonly in the fossil record are overwhelmingly represented by palmately compound leaves. These observations of modern palms parallel those of Gastaldo and Huc (1992) and Gastaldo (1992) for Nypa in the Mahakam Delta.

Absolute importance of litter and source forest (as represented by mass and basal area respectively) are not strongly correlated. Although a weak relationship exists, the rank importance of litter species is very strongly influenced by the trees most proximate to the litter sample. Fossil sampling that aims at accurately reconstructing rankorder abundance will require many samples in order to "even out" local high abundances created by overhanging canopies. Although this is a discouraging view of the number of samples required for ancient forest reconstruction, if the outcrop area is available and the plants appear to represent forest litter, there is no better opportunity to recreate so many attributes of ancient forests.

\section{Recommendations for angiosperm paleobotany}

The following recommendations are general guidelines for collecting and reconstructing autochthonous tropical angiosperm-dominated paleofloras. Because it has not been definitively shown that angiosperm ecosystems of the early Tertiary have composition and structure similar to those of today, it cannot be asserted here that these recommendations will work as well with early Eocene ecosystems as with those of the late Miocene. However, the guidelines are very likely to be applicable to tropical ecosystems in which leaves are abscised on a periodic basis and in which forest canopy is between 20 and $40 \mathrm{~m}$ in height.

(1) Individual samples should be collected from areas of about $1.5 \times 1.5 \mathrm{~m}$ and from the minimum stratigraphic thickness possible.

(2) All identifiable fragments should be counted and identified, even if only to a distinctive morphotype.

(3) A minimum average of 300 specimens per site should be censused.

(4) Each foliage abscission unit gets a count of one, even if it is a leaflet. In cases where species fragment into variable-sized units, the researcher should evaluate on the basis of their knowledge of the plants, how to count each fragment (Burnham et al., 1992).

(5) Leaf area as a proxy for leaf mass is calculated for each species.

(6) Five samples, separated from each other by $15 \mathrm{~m}$ (minimum of $8 \mathrm{~m}$ ) can be used to calculate approximate tree species richness. All taxa should be included. Species richness from five combined samples is equal to species richness in an area surrounding the samples with radius of $20 \mathrm{~m}$. The same litter richness multiplied by $3-3.5$ is equal to hectare tree species richness. 
(7) A minimum of 5 samples, preferably separated by $12 \mathrm{~m}$ minimum distance, can be used to reconstruct relative proportions of trees: vines/lianas (if they can be identified as such) in the source forest.

(8) Floras should be viewed as departing from a tropical heterogeneous forest if they show high proportions of herbaceous plants or a low degree of inter-sample heterogeneity. Great care must be taken to avoid crossing ecotones.

(9) Relative abundances of the most important litter taxa can be used to reconstruct the list of most important source taxa. With evidence from spatial variability of abundances, it may be possible to rank the source taxa. This may only be possible in forests with lower species richness (25-100 spp/ha).

\section{Acknowledgements}

The author acknowledges the generous financial support of the Smithsonian Institution BIOLAT Program for field work funding. For permission to study in the Zona Reservada del Manu, I thank the Ministerio de Agricultura and Director General de Forestal y Fauna of Perú. Field work was carried out with the able assistance of Sra. Flor Chavez Henderson. Warm thanks are extended also to Dr. Robin B. Foster for endless identifications and encouragement, without which this study could not have been completed. Robert A. Gastaldo and an anonymous reviewer provided thorough, helpful comments on the manuscript.

This represents Smithsonian Biodiversity Program Scholarly Contribution 75.

Appendix 1

Table of presence-absence of species in litter of thirteen samples from one hectare at Pakitsa, Parque Nacional Del Manu. Peru ${ }^{\text {as }}$

\begin{tabular}{|c|c|c|c|c|c|c|c|c|c|c|c|c|c|c|c|}
\hline \multirow[t]{2}{*}{ Species } & \multirow[t]{2}{*}{ Habit $^{\mathrm{b}}$} & \multicolumn{13}{|c|}{ Sample number } & \multirow[t]{2}{*}{ Fre } \\
\hline & & 10 & 9 & 11 & 12 & 13 & 2 & 4 & 6 & 8 & 1 & 3 & 5 & 7 & \\
\hline Abutu grandifolia (Martius) Sandwith & $\mathrm{SH}$ & 0 & 0 & 0 & 0 & 0 & 1 & 0 & 1 & 0 & 0 & 0 & 0 & 1 & 3 \\
\hline Aniba guyanensis?? & TR & 0 & 0 & 0 & 0 & 0 & 0 & 0 & 0 & 0 & 0 & 0 & 0 & 1 & 1 \\
\hline Anomospermum chloranthum Diels & VI & 1 & 1 & 1 & 0 & 1 & 1 & 1 & 1 & 1 & 0 & 0 & 1 & 0 & 9 \\
\hline Anomospermum grandifolia Eichler & $\mathrm{VI}$ & 1 & 1 & 1 & 0 & 1 & 1 & 0 & 0 & 0 & 0 & 0 & 0 & 0 & 5 \\
\hline $\begin{array}{l}\text { Apeiba membranacea Spruce ex } \\
\text { Bentham }\end{array}$ & TR & 1 & 1 & 1 & 1 & 1 & 1 & 0 & 0 & 1 & 0 & 0 & 0 & 0 & 7 \\
\hline Apuliat leiocarpa (Vogel) MacBride & TR & 0 & 0 & 0 & 0 & 0 & 0 & 0 & 0 & 0 & 0 & 0 & 0 & 1 & 1 \\
\hline Araceae- simple & EP & 0 & 0 & 1 & 0 & 0 & 0 & 0 & 0 & 0 & 0 & 0 & 0 & 0 & 1 \\
\hline Aspidosperma vargasii A. de Candolle & TR & 1 & 0 & 0 & 0 & 0 & 0 & 0 & 1 & 1 & $\mathrm{l}$ & 0 & 0 & 0 & 4 \\
\hline Astrocaryum macrocalyx Burret & PA & 0 & 1 & 0 & 0 & 1 & 0 & 0 & 0 & 0 & 1 & 1 & 0 & 1 & 5 \\
\hline Bauhinia spp. & VI & 0 & 0 & 0 & 0 & 0 & 0 & 0 & 0 & 0 & 1 & 0 & 0 & 0 & 1 \\
\hline Bignoniaceae vine & $\mathrm{VI}$ & 1 & 1 & 1 & 1 & 1 & 1 & 1 & 0 & 1 & 1 & 0 & 0 & 0 & 9 \\
\hline Bromeliaceae & EP & 0 & 0 & 0 & 0 & 0 & 0 & 0 & 0 & 0 & 1 & 0 & 0 & 0 & 1 \\
\hline Brosimum alicastrum Swartz. & TR & 1 & 1 & 1 & 1 & 0 & 1 & 1 & 0 & 0 & 0 & 1 & 1 & 0 & 8 \\
\hline Brosimum 1974 (sp.) & TR & 0 & 0 & 0 & 0 & 0 & 0 & 0 & 1 & 0 & 0 & 0 & 0 & 0 & 1 \\
\hline Byttneria sp. & VI & 1 & 0 & 0 & 1 & 0 & 0 & 0 & 1 & 0 & 0 & 0 & 0 & 0 & 3 \\
\hline Bryophyte & EP & 0 & 0 & 0 & 0 & 0 & 0 & 0 & 0 & 1 & 0 & 0 & 0 & 0 & 1 \\
\hline $\begin{array}{l}\text { Calyptranthes densiflora Poeppig ex } \\
\text { Berg }\end{array}$ & $\mathrm{TR}$ & 0 & 0 & 0 & 0 & 0 & 0 & 0 & 0 & 0 & 0 & 0 & 0 & 1 & I \\
\hline $\begin{array}{l}\text { Calycophyllum spruceanum (Bentham) } \\
\text { Hook ex Schumann }\end{array}$ & TR & 0 & 0 & 0 & 0 & 0 & 0 & 0 & 1 & 1 & 0 & 0 & 0 & 0 & 2 \\
\hline Ceiba samauma (Martuis) Schumamn & TR & 0 & 0 & 0 & 0 & 0 & 0 & 0 & 0 & 0 & 1 & 0 & 0 & 0 & 1 \\
\hline Celtis schippii Standley & $\mathrm{TR}$ & 1 & 0 & 0 & 0 & 0 & 0 & 0 & 1 & 0 & 0 & 1 & 1 & 1 & 5 \\
\hline Chrysochlamys ulet? Engler & TR & 0 & 0 & 0 & () & 0 & 0 & () & 0 & 0 & 0 & 0 & 0 & 1 & 1 \\
\hline $\begin{array}{l}\text { Cheiloclinium cognatum (Miers) A.C. } \\
\text { Smith }\end{array}$ & TR & 0 & 0 & 0 & 0 & 0 & 0 & 0 & 0 & 0 & 0 & 1 & 0 & 0 & 1 \\
\hline $\begin{array}{l}\text { Chorisia insignis von Humboldt, } \\
\text { Bonpland et Kunth }\end{array}$ & TR & 0 & 0 & 0 & 0 & 0 & 0 & 0 & 0 & 0 & 1 & 0 & 0 & 0 & 1 \\
\hline Clarisia racemosa Ruiz et Pavon & TR & 0 & 0 & 0 & 0 & 0 & 0 & 0 & 0 & 0 & 0 & 0 & 0 & 1 & l \\
\hline Common epiphytic vine & VI & 1 & 1 & 1 & 1 & 1 & 1 & 0 & 0 & 0 & 0 & 0 & 0 & 0 & 6 \\
\hline
\end{tabular}


Appendix 1 continued

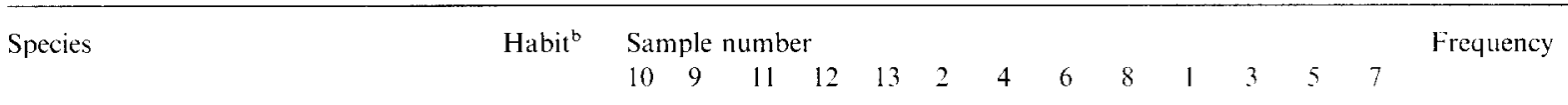

Copaifera reticulata Ducke

Costus spp.

Coussapoa oralifolia Trecul

Diosplos 0207 (sp.)

Diosplws subrotata Hiern

Dipterly alata (Aublet) Willdenow

Doliocarpuss spp.

Dripetes amazonica Steyermark

Duguctial spp.

Euterpe precatoria Martius

Fern \#1

Fern cf. Allantodiopsis

Fern cf. Asplenium

Fern cf. Faramea

Fern with reticulate veins

Fern of. Pteris

Fovillea cordifolia Cognaux

Forillea peruviana (Huber) C. Jeffreys

Ficus "hig rough"

Guarea macrophylla Vahl

Guazuma crinita Martius

Heliconia spp.

Hirtella spp.

Hirtella racemosa Lamarck

Hirtella triandra Swartz

linga spp.

Inga 0515

Inga 1016

Inga 1985

Ingu 18?0

Inga 1997

Inga 26910

Inga chartacea cf. Poeppig et

Endlicher

Inga stipularis cf. de Candolle

Iriartea deltoidea Ruiz et Pavon

Iricanthera jurtensis Warburg

Lomariopsis japurensis (Martius)

J. Smith

Lonchocarpus spicifforus Martius ex

Bentham

Luchea cimulosa Sprengl

Lunania parvifolia Spruce ex Bentham

Mabea mannensis of. Mueller Arge

Manilkura inundata (Ducke) Ducke

Matuira guianensis Aublet

Marantaceace

Matisia cordata Humboldt e1

Bonplandt

Micropholis egensis (A. de Candolle)

Pierre

Minquartia guianensis Aublet

\begin{tabular}{|c|c|c|c|c|c|c|c|c|c|c|c|c|c|c|}
\hline TR & 1 & 1 & 1 & 1 & 1 & 1 & 1 & 1 & 1 & 1 & 1 & 1 & 0 & 12 \\
\hline $\mathrm{HE}$ & 0 & 0 & 0 & 1 & 0 & 1 & 0 & 0 & 0 & 0 & 0 & 0 & 1 & 3 \\
\hline $\mathrm{HM}$ & 0 & 0 & 0 & 0 & 0 & 0 & 0 & 0 & 0 & I & 0 & 0 & 0 & 1 \\
\hline TR & 0 & 0 & 0 & 0 & 0 & 0 & 0 & 0 & 0 & I & 0 & 0 & () & 1 \\
\hline TR & 0 & 0 & 0 & 0 & 0 & 0 & 0 & 0 & 0 & 0 & 0 & 0 & 0 & 0 \\
\hline TR & 1 & 1 & 1 & 1 & 1 & 1 & 1 & 1 & 1 & 0 & 1 & 1 & 1 & 12 \\
\hline VI & 0 & 0 & 1 & 0 & 0 & 0 & 0 & 0 & 0 & 0 & 0 & 0 & 0 & 1 \\
\hline TR & 1 & 0 & 0 & 0 & 0 & 0 & 0 & 0 & 0 & 0 & () & I & (1) & 2 \\
\hline TR & 1 & 0 & 0 & 0 & 0 & 1 & 1 & 1 & 0 & 0 & 1 & 0 & 1 & 6 \\
\hline PA & 0 & 0 & 0 & 0 & 0 & 0 & 0 & 0 & 0 & 0 & 0 & 1 & 0 & 1 \\
\hline $\mathrm{FE}$ & 1 & 0 & 0 & 0 & 0 & 0 & 0 & 0 & 0 & 0 & 0 & 0) & 0 & 1 \\
\hline FE & 0 & 0 & 0 & 0 & 0 & 0 & 0 & 0 & 0 & 0 & 0 & 0 & 1 & 1 \\
\hline FE & 0 & 0 & 0 & 0 & 1 & 0 & 0 & 0 & 0 & 0 & 0 & 0 & 0 & I \\
\hline $\mathrm{FE}$ & 0 & 0 & 0 & 0 & 0 & 0 & 0 & 0 & 0 & 1 & 0 & () & 0 & 1 \\
\hline FE & 0 & 0 & 0 & 0 & 0 & 0 & 1 & 0 & 0 & 0 & 1 & 0 & 0 & 2 \\
\hline $\mathrm{FE}$ & 0 & 0 & 0 & 0 & 0 & 0 & 0 & 0 & 0 & 0 & 1 & 0 & 0 & 1 \\
\hline VI & 0 & 0 & 0 & 0 & 0 & 0 & 0 & 0 & 0 & 0 & 1 & 0) & 0 & 1 \\
\hline VI & 0 & 0 & 0 & 0 & 0 & 0 & 0 & 0 & 0 & 0 & 1 & 0 & 0 & 1 \\
\hline TR & 1 & 0 & 0 & 0 & 1 & 0 & () & 1 & 0 & 0 & () & () & 0 & 3 \\
\hline $\mathrm{TR}$ & 1 & 0 & 1 & 1 & 1 & 0 & 0 & 0 & 1 & 0 & I & 1 & () & 7 \\
\hline $\mathrm{TR}$ & 0 & 0 & 0 & 0 & 0 & 0 & 0 & 0 & 0 & 1 & 0 & 0 & () & 1 \\
\hline $\mathrm{HE}$ & 0 & 0 & 0 & 0 & 0 & 0 & 0 & 0 & 0 & 1 & 1 & 0 & 0 & 2 \\
\hline TR & 0 & 0 & 0 & 0 & 0 & 0 & 0 & 0 & () & 0 & () & 1 & 0 & 1 \\
\hline TR & 0 & 0 & 0 & 0 & 0 & 0 & 0 & 0 & 1 & 0 & 0 & 0 & 0 & l \\
\hline TR & 0 & 0 & 0 & 0 & 0 & 0 & 1 & 0 & 0 & 0 & 0 & () & 1 & 2 \\
\hline $\mathrm{TR}$ & 0 & 0 & 0 & 0 & 0 & 1 & 0 & 0 & 1 & 0 & 0 & 0 & 0) & 2 \\
\hline TR & 0 & 0 & 0 & 0 & 0 & 0 & 0 & 1 & 0 & 0 & 0 & 0 & () & 1 \\
\hline TR & 0 & 0 & 0 & 0 & 0 & 0 & 0 & 0 & 0 & 0 & 1 & 0 & 0 & 1 \\
\hline TR & 0 & 0 & 0 & 0 & 0 & 0 & 0 & 0 & 0 & 0 & 1 & 0 & 0 & 1 \\
\hline TR & 0 & 1 & 0 & 1 & 0 & 0 & 0 & 0 & 0 & 0 & 0 & 0 & 0 & 2 \\
\hline TR & 1 & 0 & 0 & 0 & 0 & 0 & 1 & 0 & 0 & 0 & 0 & 0 & 0 & 2 \\
\hline TR & 0 & 0 & 1 & 0 & 1 & 0 & 0 & 0 & 0 & 0 & 0 & l & 0 & 3 \\
\hline $\mathrm{TR}$ & 0 & 1 & 0 & 0 & 0 & 0 & 0 & 1 & 1 & 0 & 0 & 1 & () & 4 \\
\hline $\mathrm{TR}$ & 0 & 1 & 0 & 1 & 1 & 0 & 0 & 0 & 0 & 0 & () & 1 & 0 & 4 \\
\hline PA & 0 & 0 & 0 & 0 & 0 & 0 & 0 & 0 & 1 & 0 & 0 & 0 & 0 & 1 \\
\hline TR & 1 & 1 & 1 & 0 & 0 & 0 & 1 & 0 & 0 & 0 & 0 & 0 & 0 & 4 \\
\hline FE & 0 & 0 & 0 & 0 & 0 & 1 & 0 & 0 & 0 & 0 & 1 & 0 & 0 & 2 \\
\hline
\end{tabular}

TR

TR

TR

TR

TR

TR

HE

TR

TR

TR 
Appendix 1 contimued

\begin{tabular}{|c|c|c|c|c|c|c|c|c|c|c|c|c|c|c|c|}
\hline \multirow[t]{2}{*}{ Species } & \multirow[t]{2}{*}{ Habit $^{b}$} & \multicolumn{13}{|c|}{ Sample number } & \multirow[t]{2}{*}{ Frequency } \\
\hline & & 10 & 9 & 11 & 12 & 13 & 2 & 4 & 6 & 8 & 1 & 3 & 5 & 7 & \\
\hline Neea spp. & TR & 1 & 0 & 0 & 0 & 0 & 0 & 0 & 0 & 0 & 0 & 1 & 1 & 0 & 3 \\
\hline Orchidaceae & EP & 0 & 0 & 0 & 0 & 0 & 0 & 1 & 0 & 0 & 0 & 0 & 0 & 0 & 1 \\
\hline $\begin{array}{l}\text { Otoha parvifolia (Markgraf) A. } \\
\text { Gentry }\end{array}$ & TR & 0 & 1 & 0 & 0 & 1 & 1 & 1 & 1 & 0 & 1 & 1 & 1 & 0 & 8 \\
\hline Oxandra mediocris Diels & TR & 0 & 0 & 0 & 0 & 0 & 0 & 0 & 1 & 0 & 0 & 0 & 1 & 0 & 2 \\
\hline Parkict-leaf. vine habit & VI & 1 & 0 & 1 & 0 & 0 & 0 & 1 & 1 & 1 & 1 & 1 & 1 & 1 & 9 \\
\hline Palm bits & PA & 1 & 0 & 0 & 1 & 0 & 0 & 0 & 1 & 0 & 0 & 0 & 0 & 0 & 3 \\
\hline Poulscmia armata (Miguel) Standley & TR & 1 & 0 & 0 & 1 & 1 & 0 & 1 & 1 & 1 & 1 & 0 & 0 & 1 & 8 \\
\hline Pourouma cecropiaefolia Martius & TR & 0 & 0 & 0 & 0 & 0 & 0 & 0 & 0 & 0 & 0 & 0 & 1 & 0 & 1 \\
\hline Ponteria procerd (Martius) Pennell & TR & 0 & 1 & 0 & 0 & 0 & 1 & 0 & 0 & 0 & 0 & 0 & 0 & 0 & 2 \\
\hline Ponteria nitida (A. de Candolle) & TR & 1 & 1 & 0 & 1 & 1 & 0 & 1 & 1 & 1 & 1 & 1 & 0 & 1 & 10 \\
\hline Ponteria 0214 & TR & 1 & 0 & 0 & 0 & 0 & 0 & 0 & 0 & 1 & 1 & 0 & 0 & 0 & 3 \\
\hline $\begin{array}{l}\text { Pseudolmedia laevis ( Ruiz et Pavon) } \\
\text { Macbride }\end{array}$ & $\mathrm{TR}$ & 1 & I & 1 & 1 & 1 & 1 & 1 & 1 & 1 & 1 & 1 & 1 & 1 & 13 \\
\hline Pterocarpus rohrii?? Vahl & TR & 0 & 0 & 0 & 0 & 0 & 0 & 0 & 0 & 1 & 0 & 0 & 0 & 0 & 1 \\
\hline $\begin{array}{l}\text { Quararibed wittii Schumann et } \\
\text { Ulbrich }\end{array}$ & $\mathrm{TR}$ & 1 & 0 & 0 & 0 & 1 & 0 & 1 & 1 & 1 & 0 & 1 & 1 & 0 & 7 \\
\hline Rinorea viridifolia Rusby & TR & 1 & 1 & 0 & 1 & 0 & 1 & 1 & 0 & 1 & 1 & 1 & 1 & 1 & 10 \\
\hline $\begin{array}{l}\text { Ruizodendron ovalifolia (Ruiz et } \\
\text { Pavon) Fries }\end{array}$ & $\mathrm{TR}$ & 0 & 0 & 0 & 0 & 0 & 1 & 0 & 0 & 0 & 0 & 0 & 0 & 0 & 1 \\
\hline Sapium spp. & TR & 0 & 0 & 0 & 1 & 0 & 0 & 0 & 1 & 0 & 0 & 0 & 0 & 0 & 2 \\
\hline $\begin{array}{l}\text { Sche'lea cephalotes (Poeppich ex } \\
\text { Martius) Karsten }\end{array}$ & PA & 0 & 0 & 1 & 0 & 0 & 0 & 1 & 0 & 0 & 0 & 0 & 0 & 0 & 2 \\
\hline Sloanea 1034 (sp.) & TR & 0 & 0 & 0 & 0 & 0 & 0 & 0 & 0 & 0 & 0 & 0 & 1 & 0 & 1 \\
\hline Sorocea pileata W. Berger & $\mathrm{TR}$ & 0 & 1 & 0 & 0 & 1 & 0 & 0 & 0 & 0 & 0 & 0 & 0 & 0 & 2 \\
\hline Spondias mombin $\mathrm{L}$ & $\mathrm{TR}$ & 1 & 1 & 1 & 1 & 1 & 1 & l & 1 & 0 & 0 & 0 & 0 & 0 & 8 \\
\hline Tabehuia spp.? & VI & 1 & 0 & 0 & 0 & 1 & 0 & 0 & 1 & 0 & 0 & 0 & () & 0 & 3 \\
\hline Tabehuia serrata? & $\mathrm{VI}$ & 0 & 0 & 0 & 0 & 0 & 0 & 0 & 0 & 0 & 0 & 0 & 1 & 0 & 1 \\
\hline Tapura jurzana (Ule) Rizzini & $\mathrm{TR}$ & 0 & 0 & 0 & 0 & 0 & 0 & 0 & 1 & 0 & 0 & 0 & () & 0 & 1 \\
\hline Tetracera spp. & VI & 0 & 0 & 0 & 0 & 0 & 0 & 0 & 0 & 0 & 0 & 1 & 0) & 0 & 1 \\
\hline Tetragastris altissima (Aublet) Swartz & TR & 0 & 0 & 0 & 0 & 0 & 0 & 0 & 0 & 0 & 0 & 0 & 1 & 0 & 1 \\
\hline Theohroma cacao L. & TR & 0 & 0 & 0 & 0 & 0 & 1 & 0 & 1 & 1 & 0 & 0 & 0 & 0 & 3 \\
\hline Trichilia? & TR & 0 & 0 & 1 & 1 & 0 & 0 & 0 & 0 & 0 & 0 & 0 & 0 & 0 & 2 \\
\hline $\begin{array}{l}\text { Trichilia pachypoda (Rusby) C. de } \\
\text { Candolle ex Harms }\end{array}$ & $\mathrm{TR}$ & 0 & 0 & 0 & 0 & 0 & 0 & 0 & 0 & 0 & 0 & 0 & 1 & 0 & I \\
\hline Trichilia pallida Swartz & TR & 1 & 0 & 0 & 0 & 0 & 0 & 0 & 0 & 0 & 0 & 0 & 0 & 0 & 1 \\
\hline $\begin{array}{l}\text { Trichilia pleeana (A. Jussieu) C. de } \\
\text { Candolle }\end{array}$ & TR & 0 & 0 & 0 & 0 & 0 & 0 & 0 & 1 & 0 & 0 & 0 & 0) & 0 & 1 \\
\hline Trichilia poeppigii C. de Candolle & TR & 0 & 0 & 0 & 0 & 1 & 0 & 0 & 0 & 0 & 0 & 0 & 0 & 0 & 1 \\
\hline Trichilia rubra C. de Candolle & $\mathrm{TR}$ & 0 & 0 & 0 & 0 & 0 & 0 & 0 & 0 & 0 & 0 & 0 & 1 & 0 & 1 \\
\hline Virola calophylla Warburg & $\mathrm{TR}$ & 0 & 0 & 0 & 0 & 0 & 0 & 0 & 1 & 1 & 1 & 0 & 1 & 0 & 4 \\
\hline Vitex cymosa Berter & TR & 1 & 1 & 1 & 1 & 1 & 1 & 1 & 0 & 1 & 1 & 1 & 0 & 0 & 10 \\
\hline $\begin{array}{l}\text { Zizuphus cinnamomum Triana et } \\
\text { Planchon }\end{array}$ & $\mathrm{TR}$ & 1 & 0 & 0 & 0 & 0 & 0 & 0 & 0 & 1 & 0 & 0 & 0 & 1 & 3 \\
\hline Identified species richness & & 43 & 32 & 31 & 33 & 37 & 25 & 27 & 36 & 35 & 25 & 29 & 34 & 29 & \\
\hline Number unidentified taxa & & 9 & 6 & 7 & 4 & 7 & 10 & 11 & 18 & 11 & 7 & 13 & 7 & 3 & \\
\hline Total taxa in sample & & 52 & 38 & 38 & 37 & 44 & 35 & 38 & 54 & 46 & 32 & 42 & 41 & 32 & \\
\hline
\end{tabular}

a $0=$ absent, $1=$ present.

${ }^{\mathrm{b}}$ Habit codes: $E P=$ Epiphyte; $F E=$ Fern; $H E=$ Herb; $H M=$ Hemiepiphyte: $P A=$ Palm; $S H=$ Shrub; $T R=$ Tree; $V I=$ Vine

Species acronyms shown in Fig. 7 are composed of first two letters of genus and specific epithet. Identities of many species are provisional, particularly for difficult groups such as Pouteria and Trichilia. 


\section{References}

Boyd, A.E. III, 1985. A Miocene flora from the Oviatt Creek Basin. Clearwater County, Idaho. M.S. Thesis. Univ. Idaho, Moscow. ID, 168 pp. (unpubl.).

Burnham. R.J., 1989. Relationships between standing vegetation and leaf litter in a paratropical forest: implications for paleobotany. Rev, Palaeobot. Palynol., 58: 5-32.

Burnham. R.J.. 1993. Reconstructing richness in the plant fossil record. Palaios, 8(4): 376-384.

Burnham. R.J., in press. Paleoecological and floristic heterogeneity in the plant fossil record: An analysis based on the Eocene of the Washington. US Geol. Surv. Bull.

Burnham. R.J., Wing, S.L. and Parker, G.G., 1992. The reflection of deciduous forest communities in leaf litter: implications for autochthonous litter assemblages from the fossil record. Paleobiology, 18(1): 30.49 .

Castellanos, A., Mooney, H.A., Bullock, S.H., Jones, C. and Robichaux, R.. 1989. Leaf, stem, and metamer characteristics of vines in a tropical deciduous forest in Jalisco, Mexico. Biotropica, 21: $41-49$.

Cross. A.T. and Taggert, R.E., 1982. Causes of short-term sequential changes in fossil plant assemblages: Some considerations based on a Miocene flora of the northwestern USA. Ann. Mo. Bot. Gard., 69: 679-734.

Foster. R.B., 1990. The floristic composition of the Rio Manu floodplain forest. In: A. Gentry (Editor), Four Neotropical Forests. Yale Univ. Press, New Haven, CT, pp. 99 111.

Gatstaldo, R.A., 1989. Preliminary observations on phytotaphonomic assemblages in a subtropical/temperate Holocene bayhead delta: Mobile Delta. Gulf Coastal Plain, Alabama. Rev. Palaeobot. Palynol., 58: 61-83.

Gastaldo. R.A., 1992. Taphonomic considerations for plant evolutionary investigations. Palaeobotanist, 41: 211-223.

Gastaldo, R.A. and Huc, A.-Y., 1992. Sediment facies, depositional environments, and distribution of phytoclasts in the Recent Mahakam River Delta, Kalimantan, Indonesia. Palaios, 7(6): 574 590.

Gentry, A.H., 1983. Lianas and the "paradox" of contrasting latitudinal gradients in wood and litter production. Trop. Ecol., 24: 63 -67.

Gentry, A.H. and Dodson, C.. 1987. Contribution of nontrees to species richness of a tropical rain forest. Biotropica, 19(2): 149156

Greenwood. D.R.. 1991. The taphonomy of plant macrofossils.
In: S.K. Donovan (Editor), The Processes of Fossilization. Belhaven Press, London, pp. 141-169.

Greenwood, D.R., 1992. Taphonomic constraints on foliar physiognomic interpretations of Late Cretaceous and Tertiary paleoclimates. Rev. Palaeobot. Palynol.. 71: $149 \cdot 190$

Johnson, K.R., 1992. Leaf-fossil evidence for extensive floral extinctions at the Cretaceous-Tertiary boundary, North Dakota, USA. Cretaceous Res., 13:91 117.

Kalliola, R., Salo, J. and Makinen, Y.. 1987. Regeneracion natural de selvas en la amazonia Peruana, 1: Dinamica fluvial y sucesion ribereña. Univ. Nac. Mayor San Marcos, Lima, Mem. Mus. Hist. Nat. "Javier Prado", 19A, 102 pp.

Lee, W.T. and Knowlton, F.H., 1917. Geology and Paleontology of the Raton Mesa and other Regions in Colorado and New Mexico. US Geol. Surv. Prol. Pap., $101,450 \mathrm{pp}$.

Lott, E.J., Bullock, S.H and J.A. Solis-Magallanes., 1987. Floristic diversity and structure in upland and arroyo forests in coastal Jalisco. Biotropica, 19: 228-235.

MacGinitie, H.D., 1974. An Early Middle Eocene flora from the Yellowstone--Absaroka Volcanic Province. Northwestern Wind River Basin, Wyoming. Univ. Calif. Publ. Geol. Sci.. 108, 103 pp.

Scott, A.C., 1977. A review of the ecology of Upper Carboniferous plant assemblages with new data from Strathclyde. Palaeontology, 20(2): 447473.

Spicer, R.A., 1988. Quantitative sampling of plant megafossil assemblages. In: W.A. DiMichele and S.L. Wing (Editors). Methods and Applications of Plant Paleoecology. Paleontol. Soc. Spec. Publ. 3: 29 51.

Spicer, R.A. and Hill, C.R., 1979. Principal components and correspondence analyses of quantitative data from a Jurassic plant bed. Rev. Palaeobot. Palynol., 28: 273 . 299.

Terborgh. J., 1983. Five New World Primales: A Study in Comparative Ecology. Princeton Univ. Press, Princeton. NJ. 260 pp.

Terborgh. J., 1990. An overview of research at Cocha Cashu Biological Station. In: A. Gentry (Editor), Four Neotropical Forests. Yale Univ. Press, New Haven, CT, pp. $48-59$.

Wing, S.L., 1984. Relation of paleovegetation to geometry and cyclicity of some fluvial carbonaceous deposits. J. Sediment. Petrol. 54(1): 52-66.

Wing. S.L.. Hickey, L.J. and Swisher. C.C., 1993. Implications of an exceptional fossil flora for late Cretaceous vegetation. Nature, 363: 342-345. 